\title{
Evaluation of Physical, Functional, Nutritional and Textural Qualities of Little Millet (Panicum sumatrense L.) Flakes
}

\author{
S. D. Anusha ${ }^{1 *}$, K. B. Suresha ${ }^{2}$ and V. Kumargoud ${ }^{1}$ \\ ${ }^{1}$ College of Agricultural Engineering, UAS, GKVK, Bengaluru-65, India \\ ${ }^{2}$ Centre of Excellence for Nutri-Cereals, AICRP on PHET, \\ $U A S, G K V K$, Bengaluru-560065, India
}

*Corresponding author

\section{A B S T R A C T}

\section{Keywords}

Millets, Little millet flakes, RTE, AOAC and Nutritional composition

Article Info

Accepted:

22 February 2020

Available Online:

10 March 2020
Modern man faces a great many awful diseases and disorders which were not even known to ancient man. Dietary patterns were merely responsible for this deadly situation. Hence replacing empty calorie foods with nutritious grain-millets thus helps to reduce the burden of malnutrition and also prevents and manages modern metabolic disorders. The present study focuses on the evaluation of physicochemical, functional, textural and nutrient composition of little millet flakes. Proximate analysis of little millet flakes was evaluated by the standard procedures of AOAC. The little millet flakes exhibited dull, creamy white, small, thin and crispy, irregular shaped, dry and light in weight hues with ' $L$ ' (67.07), 'a' (2.70) and 'b' (15.09) values. Bulk density and true density were $1.09 \mathrm{~g} / \mathrm{mL}$ and 1.26 $\mathrm{g} / \mathrm{mL}$ respectively. The millet flakes had water holding capacity of $51.95 \%$ and water absorption capacity of $194.67 \%$. The hardness of little millet flakes was 319.157 force/g respectively. The millet flakes had moisture, fat, protein, total ash, crude fibre and carbohydrates of $10.46,2.70,8.0,2.04,8.74$ and $68.06 \%$ respectively.

\section{Introduction}

Little millet is one of the oldest cultivated millet. It is also now as same (Kannada), and it is grown in temperate zones of Asia, China, East Asia, India, Indochina, and Malaysia. In India, Little millet (Panicum sumatrense L.) crops mainly grown in Karnataka and Tamil
Nadu. It contains a high amount of carbohydrates, proteins, minerals and vitamins, because of their nutritional superiority they are also referred to as nutrias grains or Nutri millets. The protein has a balanced profile of amino acids and a good source of methionine, cysteine and lycine. Compared to other minor millets and staple 
food crops like rice and wheat in little millet fairly good amount of iron content was observed (Gopalan et al., 2010).

Little millet has fat $4.7 \mathrm{~g}$, crude fiber $7.7 \mathrm{~g}$, iron $9.3 \mathrm{mg}$ and phosphorus $220 \mathrm{mg}$ per $100 \mathrm{~g}$ which is comparable to cereals and other millets. The dietary fiber content of little millet is the contributing factor for its low glycaemic index and a recent study conducted on little millet exhibits a hypoglycaemic property due to its high dietary fibre. controls blood sugar, hyperlipidemia, cardiovascular diseases, obesity and diabetes (Itagi et al., 2012).

Studies show that individuals on a millet based diet suffer less from degenerative diseases. Low glycemic index nutritious food products made from little millet can be used as an effective support therapy for diabetes care. Hence owing to the nutritional and health benefits of little millet, studies have been carried out to develop little millet flakes so as to benefit the people at large (Itagi et al., 2012 and Coulibaly et al., 2012).

While millets nutritional qualities have been well documented, its utilization for food is confined to the traditional consumers in tribal communities, mainly due to the lack of consumer friendly, ready-to-cook or ready-toeat products. If the millet is made available to the community in a convenient ready to eat and ready to cook forms, nutritional and nutraceutical benefits will hit both farming communities and also health conscious consumers.

\section{Materials and Methods}

\section{Procurement of raw materials}

The raw material used in the study such as are Little millet was procured from the Zonal Agricultural Research Station, University of
Agricultural Sciences, G.K.V.K, Bengaluru.Physical, chemical, functionaland textural characteristics of little millet flakes were assessed by following standard procedures.

\section{Physical characteristics}

\section{Volume}

Thousand randomly selected grains were dropped in a measuring cylinder containing known volume of distilled water. The difference in volume was recorded in $\mathrm{ml}$.

\section{Bulk density}

Bulk density was calculated using the formula:

Bulk density $(\mathrm{g} / \mathrm{mL})=\frac{\text { Grain Weight }(\mathrm{g})}{\text { Grain Volume }(\mathrm{mL})}$

\section{True density}

The true density of the grain was calculated by using the formula

True density $(\mathrm{g} / \mathrm{mL})=$

$$
\frac{\text { Weight of the grains }(\mathrm{g})}{\text { Volume of grains excluding pore space }(\mathrm{mL})}
$$

\section{Color}

Colour of randomly selected flakes and grains were taken separately and subjected to colour assessment in Spectrophotometer Konica Minolta, CM-2600/2500d model.

\section{Functional properties}

\section{Water holding capacity}

Approximately $5 \mathrm{~g}$ of finely ground sample was weighed and allowed to rehydrate overnight in distilled water $35 \mathrm{ml}$, after 
draining it was reweighed and water holding capacity was calculated as follows (Deshpande and Poshadri, 2011).

Water holding capacity $(\%)=\frac{\text { Weight of the wet sample atter draining }(\mathrm{g}) \text {-Weight of dry sample }(\mathrm{g})}{\text { Weight of dry sample }(\mathrm{g})} \times 100$

\section{Water/oil absorption capacity}

The samples were ground to a fine powder and introduced into a centrifuge tube and thoroughly mixed with $30 \mathrm{~mL}$ distilled water/ground nut oil. The sample was allowed to stand for $30 \mathrm{~min}$ and centrifuged at 1500 rpm speed for 30 minutes. The free water/oil was decanted into a graduated cylinder and volume recorded. The value was expressed as the grams of water/oil absorbed per gram of sample (Nawabueze, 2006).

\section{Chemical properties}

The moisture content of the sample was analyzed by the standard procedure using hot air oven maintained at $105^{\circ} \mathrm{C}$ for 24 hours AOAC (Association of Official Analytical Chemists). The protein content of the sample was analyzed by the standard procedure of using microkjeldhal method(AOAC, 2005). The fat content of the sample was analyzed by the standard procedure using solvent extraction method (AOAC, 1997). The ash content of the sample was analyzed by the standard procedure of using muffle furnace (AOAC, 2005). The crude fibre sample was analyzed by the standard procedure using fibre extraction unit(AOAC, 1990). Carbohydrate of the sample was determined by subtracting the sum of protein, fat, fibre, ash and moisture content from 100 using standard procedure (AOAC, 1980).

\section{Texture of flakes}

Texture profile analysis of the samples was performed using a texture analyzer (TAXT2, Stable Micro Systems, Surrey, UK) on the option of breakfast cereal products. A single flake was compressed with P50 compression probe. All measurements were performed on randomly chosen 25 flakes and the results were analyzed using the software, Exponent (Stable Micro Systems, Surrey, UK) and average force was expressed as $\mathrm{g}$ force.

\section{Statistical analysis}

The evaluation of little millet flakes were analysed using a factorial CRD $4 \times 4 \times 3$ to compare the variance in impact of processing on physical characteristics, chemical composition and textural qualities of little millet flakes employing the tools described.

\section{Results and Discussion}

Conventional batch processing methods were followed for the development of Ready to Cook or Ready to Eat little millet flakes. Process parameters for producing the little millet flakes were soaking (16 hours), cooking $\left(85^{\circ} \mathrm{C}\right.$ for 10 minutes) and drying $\left(40^{\circ} \mathrm{C}\right.$ for 1 hour) were found to be optimum for producing good quality flakes. Millets are healthy nutrient sources and therefore, their name has become synonymous with health and wellbeing. Physical, Chemical and Nutritional composition of little millet flakes is presented in Table 1.

\section{Physical properties}

The various physical characteristics of little millet flakes were analyzed and the results are presented in Table 1. It was observed that the little millet flakes were dull, creamy white, thin, irregular shaped, dry, light and crispy in colour. The mean value of color of little millet flakes $L^{*}, a^{*}$ and $b^{*}$ is 67.07, 2.70 and 15.09 with critical difference (CD) of $0.354,0.619$ and 1.687. The mean value of flake volume was $9.50 \mathrm{~mL}$ with $\mathrm{CD}$ of 0.265 . The mean value of bulk density and true density little 
millet flakes was 1.09 and $1.26 \mathrm{~g} / \mathrm{mL}$ with $\mathrm{CD}$ of 0.054 and 0.166 . There was no heterogeneity between all the physical properties with respect to $\mathrm{CD}$. The physical characteristics play very important role in analyzing its process ability. The result on physical characteristics of little millet RTC flakes in the present study is in agreement with the reports of Kotagi, (2011). Colour is an important quality factor directly linked to the acceptability of food products. BulkDensity is the standard for good flaking quality. Hence, lower bulk density was recorded by little millet flakes. The results of physical characteristics of little millet flakes were similar to those obtained for roller dried foxtail millet flakes (Singh et al., 2004).

\section{Proximate composition of little millet flakes}

The nutrient composition of little millet flakes is presented in Table 1.The data showed significant difference in (\%) was noticed among moisture, protein, fat, total ash, crude fiber and carbohydrate of little millet flakes were in the range of 10.32-10.76, 8.12$8.18,2.52-2.87,2.02-2.10,8.14-8.98$ and 68.42-69.76 per cent respectively. Little millet flakesobserved significantly less amount of protein, fat, fiber, ash and carbohydrates when compare to grain. The mean value of moisture, protein, crude fat, total ash, crude fibre and carbohydrates of littlemillet flakes was observed to be 10.46 , $8.0,2.70,2.04,8.74$ and 68.08 per cent respectively.

Table.1 Physical, chemical and functional properties of little milletflakes

\begin{tabular}{|c|c|c|c|c|c|}
\hline $\begin{array}{l}\text { Sl. } \\
\text { No. }\end{array}$ & Parameters & Range & Mean & SEm \pm & $\begin{array}{c}\text { CD } \\
(5 \%)\end{array}$ \\
\hline & \multicolumn{5}{|c|}{ Physical properties } \\
\hline \multirow[t]{3}{*}{1} & Colour $L^{*}$ & $66.98-67.18$ & 67.07 & 0.058 & 0.354 \\
\hline & $a^{*}$ & $2.50-2.80$ & 2.70 & 0.102 & 0.619 \\
\hline & $b^{*}$ & $14.54-15.44$ & 15.09 & 0.277 & 1.687 \\
\hline 2 & Bulk density $(\mathrm{g} / \mathrm{mL})$ & $1.07-1.10$ & 1.09 & 0.09 & 0.054 \\
\hline 3 & True density $(\mathrm{g} / \mathrm{mL})$ & $1.21-1.30$ & 1.26 & 0.027 & 0.166 \\
\hline \multirow[t]{2}{*}{4} & Volume $(\mathrm{mL})$ & 9.43-9.58 & 9.50 & 0.044 & 0.265 \\
\hline & \multicolumn{5}{|c|}{ Functional Properties } \\
\hline 5 & Water holding capacity (\%) & $46.11-57.62$ & 51.95 & 3.324 & 20.22 \\
\hline \multirow[t]{2}{*}{6} & Water absorption capacity (\%) & 194.34-194.67 & 194.57 & 0.113 & 0.691 \\
\hline & \multicolumn{5}{|c|}{ Chemical Properties } \\
\hline 7 & Moisture (\%) & $10.32-10.76$ & 10.46 & 0.085 & 0.518 \\
\hline 8 & Crude protein (\%) & $8.12-8.18$ & 8.0 & 0.093 & 0.565 \\
\hline 9 & Crude fat $(\%)$ & $2.52-2.87$ & 2.70 & 0.035 & 0.215 \\
\hline 10 & Total ash (\%) & $2.02-2.10$ & 2.04 & 0.015 & 0.093 \\
\hline 11 & Crude fiber $(\%)$ & 8.14-8.98 & 8.74 & 0.067 & 0.405 \\
\hline 12 & Carbohydrate (\%) & $68.42-69.76$ & 68.08 & 0.414 & 2.518 \\
\hline
\end{tabular}

$L^{*}$ indicates black to white $a^{*}$ indicates redness to greenness and $b^{*}$ indicates yellowness to blueness 
Table.2 Textural attributes of optimized flakes

\begin{tabular}{|l|l|c|c|c|c|}
\hline SI. No. & Textural attributes & Value & SEm \pm & CD & F-test \\
\hline $\mathbf{1}$ & Hardness (g) & 319.157 & 0.04 & 0.12 & $*$ \\
\hline $\mathbf{2}$ & Fracturability (g) & 87.27 & 0.72 & 2.08 & $*$ \\
\hline $\mathbf{3}$ & Springiness & 0.2 & 0.01 & 0.02 & $*$ \\
\hline $\mathbf{4}$ & Cohesiveness & 0.793 & 0.01 & 0.02 & $*$ \\
\hline $\mathbf{5}$ & Gumminess & 237.995 & 20.85 & 60.06 & $*$ \\
\hline $\mathbf{6}$ & Chewiness & 3.635 & 0.04 & 0.02 & $*$ \\
\hline $\mathbf{7}$ & Resilience & 0.961 & 0.07 & 0.21 & $*$ \\
\hline
\end{tabular}

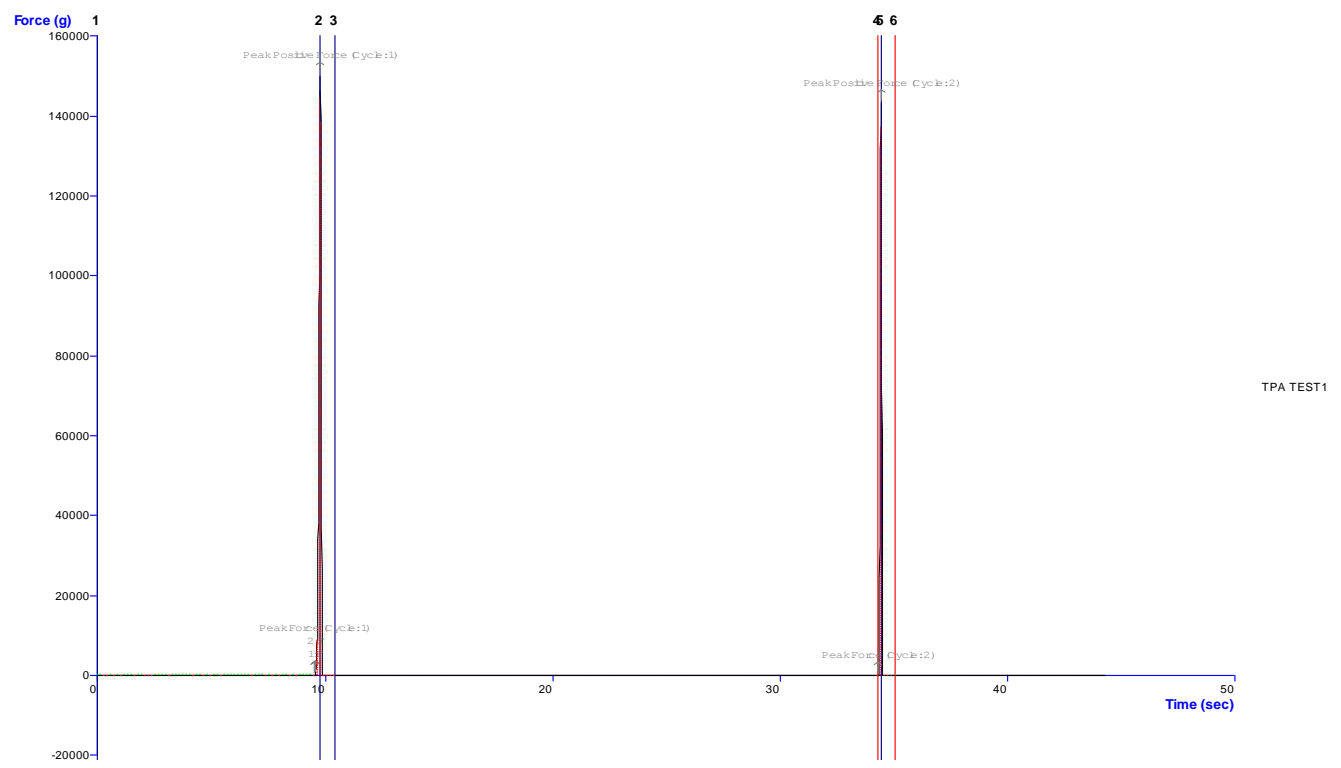

Fig.1 Effect of force on little millet flakes using texture analyser

There was a significant need for the composition of little millet flakes in terms of their nutrient content to determine its potential benefits. Similar results were obtained from the studies offor rolled barnyard millet flakes and little millet flakes.(Lenkannavar, 2010)

\section{Functional characteristics of little millet flakes}

The data presented in Table 1. Showed the mean value of Water holding capacity, Water absorption capacity were 51.95 and 194.57 per cent, respectively. Functional characteristics are the important parameters, which decide the resultant application not only in the processing but also in manufacturing of various values added products. Similar findings were indicated in soy flakes (Bargale et al., 1991).

\section{Textural attributes of optimized little millet} flakes

The values of hardness, fracturability, springiness, cohesiveness, gumminess chewiness and resilience along with the area under curve is presented for little millet flakes Fig. 1.The force-time at different peaks and 
area obtained for the compression test of selected flakes are presented in Table 2. The analyzer also shows the graphs obtained during the actual test run of compression tests. The mean force required to break the flakes was $319.157 \mathrm{~g}$ with a CD of 0.12 . The mean value of fracture ability $(\mathrm{g})$, springiness, cohesiveness, gumminess, chewiness and resilience were recorded to be $87.27 \mathrm{~g}, 0.2$, $0.793,237.995,3.635$ and 0.961 with $\mathrm{CD}$ of $2.08,0.02,0.02,60.06,0.02$ and 0.21 , respectively. The present study on physicochemical, nutritional and textural attributes of little millet flakes concluded that the diversification of diet with little millet based products would help to achieve food and nutritional security effectively and economically.

\section{References}

AOAC. Official Methods for computation of carbohydrates and energy. Association of Official Analytical Chemists. $14^{\text {th }}$ Edition. Washington, D.C. USA; 1980.

AOAC. Official Methods of Analysis for ash, moisture in flour. Association of Official Analytical Chemists.; 18th Edition. Arlington VA 2209, USA. AOAC 929.09 \& 03, chap 32. 2005;1-2.

AOAC. Official Methods of Analysis for crude fiber. Association of Official Analytical Chemists. 15th Edition. Washington, D.C. USA; 1990.

AOAC. Official Methods of Analysis for fat (crude) or ether extract in flour. Association of Official Analytical Chemists; 16th Edition. 3rd Revision. Gaithersburg, Maryland 20877-2417. AOAC 920.85, chap 32. 1997;05.

AOAC. Official Methods of Analysis for protein. Association of Official Analytical Chemists.; 18th Edition. Arlington VA 2209, USA. AOAC 984.13, chapter 04. 2005;31.

Bargale, P. C., Joshi, K. C. And Krishna,
1991, Storability of soy flakes in different packaging materials under warm conditions. Indian.J. Nutr. Dietet., 28:140.

Coulibaly, A., Kouakou, B. and Chen, J., 2012. Extruded adult breakfast based on millet and soybean: Nutritional and functional qualities, source of low glycemic food. J. Nutr.Food Sci., 2(7), http://dx. doi. org/10. 4172/2155-9600. 1000151.

Deshpande, H. W., and Poshadri, A., 2011. Physical and sensory characteristics of extruded snacks prepared from Foxtail millet based composite flours. Int. Food Res. J., 18: 751-756.

Gopalan, C., Ramshatri, B. V. And Balasubramanian, S. C., 2010, Nutritive value of Indian foods. Nat. Institute Nutri., 24(2): 1-48.

Itagi, S., Naik, R., Bharati, P. And Sharma, P., 2012, Readymade foxtail millet mix for diabetics. Int. J. Sci. Nature., 3(1): 4750 .

Kotagi, K., 2011. Little millet (Panicum miliare) flakes: Development, value addiction, quality evaluation, consumer acceptability and commercialisation. Ph. D. Thesis, Univ. Agric. Sci., Dharwad (India).

Lenkannavar, R., 2010. Development and quality evaluation of barnyard millet flakes. M. H. Sc. Thesis, Univ. Agric.Sci., Dharwad (India).

Matz, S.A., 1962 Food texture, AVI publishing Co., Westport, C.T.

Nawabueze, T., 2006. Water / oil absorption and solubility indices of extruded African bread fruit blends. J. Food. Technol., 4(1): 64-69.

Singh, R. U., Latha, S and Malleshi, N. G., 2004. The functional properties of popped, flaked, extruded and rollerdried foxtail millet (Setaria italica). Int. J. Food Sci. Technol., 39: 907-91. 


\section{How to cite this article:}

Anusha. S. D., K. B. Suresha and Kumargoud. V. 2020. Evaluation of Physical, Functional, Nutritional and Textural Qualities of Little Millet (Panicum Sumatrense L.) Flakes. Int.J.Curr.Microbiol.App.Sci. 9(03): 2857-2863. doi: https://doi.org/10.20546/ijcmas.2020.903.329 